\title{
Article \\ Therapeutic Application of Metal-Organic Frameworks Composed of Copper, Cobalt, and Zinc: Their Anticancer Activity and Mechanism
}

\author{
Ihn Han ${ }^{1}$, Seung Ah Choi ${ }^{2,3}$ and Do Nam Lee ${ }^{4, *}$ \\ 1 Plasma Bioscience Research Center, Applied Plasma Medicine Center, Kwangwoon University, \\ Seoul 01897, Korea; difflvin@hotmail.com \\ 2 Division of Pediatric Neurosurgery, Seoul National University Children's Hospital, Seoul 03080, Korea; \\ aiipo@snu.ac.kr \\ 3 Biomedical Research Institute, Seoul National University, Seoul 03080, Korea \\ 4 Ingenium College of Liberal Arts (Chemistry), Kwangwoon University, Seoul 01897, Korea \\ * Correspondence: donamlee@hanmail.net
}

check for

updates

Citation: Han, I.; Choi, S.A.; Lee, D.N. Therapeutic Application of Metal-Organic Frameworks Composed of Copper, Cobalt, and Zinc: Their Anticancer Activity and Mechanism. Pharmaceutics 2022, 14, 378. https://doi.org/10.3390/ pharmaceutics14020378

Academic Editors: Abhishek Sahu, Thavasyappan Thambi and Carlos Alonso-Moreno

Received: 28 December 2021 Accepted: 6 February 2022

Published: 8 February 2022

Publisher's Note: MDPI stays neutral with regard to jurisdictional claims in published maps and institutional affiliations.

Copyright: () 2022 by the authors Licensee MDPI, Basel, Switzerland. This article is an open access article distributed under the terms and conditions of the Creative Commons Attribution (CC BY) license (https:/ / creativecommons.org/licenses/by/ $4.0 /)$.

\begin{abstract}
Effective penetration into cells, or binding to cell membranes is an essential property of an effective nanoparticle drug delivery system (DDS). Nanoparticles are generally internalized through active transport mechanisms such as apoptosis, and cargo can be released directly into the cytoplasm. A metal-organic framework (MOF) is a network structure consisting of metal clusters connected by organic linkers with high porosity; MOFs provide a desirable combination of structural features that can be adjusted with large cargo payloads, along with $\mathrm{Cu}, \mathrm{Co}$, and $\mathrm{Zn}-\mathrm{MOFs}$, which have the chemical stability required for water-soluble use. Bioactive MOFs containing copper, cobalt, and zinc were prepared by modifying previous methods as therapeutic drugs. Their structures were characterized via PXRD, single-crystal crystallographic analysis, and FT-IR. The degradability of MOFs was measured in media such as deionized water or DPBS by PXRD, SEM, and ICP-MS. Furthermore, we investigated the anticancer activity of MOFs against the cell lines SKOV3, U87MG, and LN229, as well as their biocompatibility with normal fibroblast cells. The results show that a nanoporous 3D $\mathrm{Cu}-\mathrm{MOF}$ could potentially be a promising candidate for chemoprevention and chemotherapy.
\end{abstract}

Keywords: metal-organic framework; degradability; anticancer; biocompatibility; apoptosis

\section{Introduction}

Cancer has become a large threat to human beings in recent decades [1]. In response to evolved cancers, more efficient treatments have been developed in the areas of surgery, chemotherapy, radiotherapy, and proton-beam, molecular-targeted, and immune therapies. Among these therapies, chemotherapy is the most common treatment and predominantly utilized to treat cancer [2-7]. However, it sometimes exhibits severely undesirable side effects on normal cells, resulting in fatigue, eating disorders, vomiting, hair loss, etc. To enhance therapeutic efficiency and reduce side effects, a variety of drug vehicles have been explored to release the drug to its target within an adequate time responding to the $\mathrm{pH}$, temperature, light, pressure, or magnetic field [8-18]. An ideal drug delivery system requires several features such as large drug loading capacity, controlled release, and high biocompatibility. Although porous inorganic oxides, organic micelles, liposomes, dendrimers, and metal nanoparticles have been introduced as new drug delivery systems, they also have some intrinsic drawbacks derived from each delivery method [19-21]. Many researchers have paid attention to new drug delivery systems exhibiting controlled low cytotoxicity in chemotherapy. Since 2006, metal-organic frameworks (MOFs) have attracted interest for drug delivery and theragnostic science due to their controllable pore size, easily tunable compositions, and high surface area to volume, which is advantageous 
for drug loading capacity and stimulus-sensitive responses [22-27]. In general, MOFs can be prepared through the self-assembly reaction of metal ions or clusters with multidentate organic ligands and are easily designed as ideal drug delivery candidates through interesting geometries and connectivity [28-33]. More specifically, MOFs including $\mathrm{Cr}$, $\mathrm{Fe}, \mathrm{Zn}$, and $\mathrm{Zr}$ have been studied as drug delivery vehicles loading IBU (ibuprofen), 5-Fu (5-fluoroucil), cis-platin, caffeine, etilefrine hydrogen chloride, etc. The favorable drug loading capacities of these MOFs were accomplished through encapsulation by adsorption, or hydrogen bonding and electrostatic interaction [34-41]. For instance, a photosensitizerloaded MOF-199, PS@MOF-199 NP, was developed for photodynamic therapy, leading to moderate photosensitization to provide an effective photodynamic therapy with enhanced therapeutic effects and minimal phototoxicity via decreased endogenous GSH levels [18]. $\mathrm{A} \mathrm{Cu}$ (II)-based MOF with a 1D channel was developed for anticancer chemotherapy on OS-732 osteosarcoma cells, and this study revealed that the Cu-MOF facilitated apoptosis of the cancer cells and caused ROS accumulation on cancer cells [42]. Furthermore, MOFs can be composed of bioactive metals and ligands, which offer a therapeutic effect for various bacteria and cancers [27-38]. However, some MOFs are known to release excess metal ions which may be toxic to normal cells as well as cancer cells. Hence, there is also an interest in robust MOFs which provide intrinsic therapeutic effects without any other drug loading or decomposition releasing cytotoxic metal ions.

Herein, we present the preparation of MOFs containing glutarate (glu) and 1,2-bis(4pyridyl)ethane (bpa) ligands coordinated to copper, cobalt, and zinc though modified solvothermal methods. Their stabilities were studied in physiological media, and their resulting effects on bioactivity are discussed. The anticancer properties toward various cancer cells and biocompatibility to normal cells were tested. We propose the potent possibility of therapeutic applications of robust MOFs through investigation of their cell death mechanism. In this study, the anticancer properties of the MOFs and their underlying mechanisms are reported based on in vitro experimental evidence. Taken together, this scientific evidence of MOFs with anticancer properties could facilitate future research to explore potential therapeutic targets in cancer therapy.

\section{Experimental Methods}

\subsection{Preparation of Cu-MOF 1, [C $\left.\mathrm{Cu}_{2}(\mathrm{Glu})_{2}(\mu-b p a)\right] \cdot 3 \mathrm{H}_{2} \mathrm{O}$}

A three-dimensional nanoporous $\mathrm{Cu}-\mathrm{MOF} \mathbf{1}$, formulated as $\left[\mathrm{Cu}_{2}(\mathrm{Glu})_{2}(\mathrm{bpa})\right] \cdot 3 \mathrm{H}_{2} \mathrm{O}$, was prepared from a mixture of $\mathrm{Cu}\left(\mathrm{NO}_{3}\right)_{2} \cdot 3 \mathrm{H}_{2} \mathrm{O}(0.48 \mathrm{~g}, 2.0 \mathrm{mmol})$, glutaric acid $(0.26 \mathrm{~g}$, $2.0 \mathrm{mmol})$, and 1,2-bis(4-pyridyl)ethane $(0.18 \mathrm{~g}, 1.0 \mathrm{mmol})$ in distilled water $(200 \mathrm{~mL})$ containing $1.0 \mathrm{M} \mathrm{NaOH}(2 \mathrm{~mL})$ as per previously reported literature methods [43]. In more detail, the reaction mixture was added to a high-vacuum vessel and placed in an oven at $80^{\circ} \mathrm{C}$ for $48 \mathrm{~h}$. After cooling to $25^{\circ} \mathrm{C}$, the obtained crystals were separated by filtration, washed with distilled water, and air dried overnight. Single-crystal crystallography, PXRD, and SEM were utilized for structural determination.

\subsection{Preparation of Co-MOF 2, $\left[\mathrm{Co}_{2}(\mathrm{Glu})_{2}(\mu-\mathrm{bpa})_{2}\right] \cdot 4 \mathrm{H}_{2} \mathrm{O}$}

$\mathrm{Co}\left(\mathrm{NO}_{3}\right)_{2} \cdot 6 \mathrm{H}_{2} \mathrm{O}(0.116 \mathrm{~g}, 0.4 \mathrm{mmol})$ was mixed well with glutaric acid $(0.053 \mathrm{~g}, 0.4 \mathrm{mmol})$ and 1,2-bis(4-pyridyl)ethane ( $0.147 \mathrm{~g}, 0.8 \mathrm{mmol})$ in $10 \mathrm{~mL}$ of $\mathrm{N}, \mathrm{N}$-dimethylformamide (DMF) [44] This mixture was placed in a Teflon-lined high-pressure vessel, which was placed in an oven at $100{ }^{\circ} \mathrm{C}$ for $72 \mathrm{~h}$ and then cooled to $25^{\circ} \mathrm{C}$. Purple-colored crystals were collected by filtration, washed with DMF, and air dried overnight. The structure of Co-MOF 2 was determined using single-crystal crystallography, PXRD, and SEM.

\subsection{Preparation of $\mathrm{Zn}-\mathrm{MOF} 3$, [ $\left.\left.\mathrm{Zn}\left(\mathrm{H}_{2} \mathrm{O}\right)(\mathrm{Glu})\right\}_{2}(\mu-b p a)\right]$}

The $\mathrm{Zn}-\mathrm{MOF} 3$ was synthesized by hydrothermal reactions, using methods modified from previous reports [45]. Briefly, $\mathrm{Zn}\left(\mathrm{NO}_{3}\right)_{2} \cdot 6 \mathrm{H}_{2} \mathrm{O}(0.1 \mathrm{mmol})$, glutaric acid $(0.1 \mathrm{mmol})$, and 1,2-bis(4-pyridyl)ethane $(0.2 \mathrm{mmol})$ were mixed in distilled water. Subsequently, this mixture was placed in a Teflon-lined high-pressure vessel, which was placed in an oven 
at $80{ }^{\circ} \mathrm{C}$ for $48 \mathrm{~h}$ and then cooled to $25{ }^{\circ} \mathrm{C}$. The as-prepared sample of $\mathrm{Zn}-\mathrm{MOF}$ was characterized by single-crystal crystallography, PXRD, and SEM.

\subsection{Instrumentation}

The PXRD patterns of the MOFs were recorded using a Rigaku MiniFlex diffractometer (Rigaku Corp., Neu-Isenburg, Germany). FT-IR spectroscopy was performed using an INVENIO-R (Bruker, Billerica, MA, USA). The surface morphologies of the MOFs were characterized by SEM (JSM-5800F, JEOL, Tokyo, Japan). Inductively coupled plasma mass spectrometry (ICP-MS, Agilent Marker 7700, RF Generator Power 1550W, Tokyo, Japan) measurements were performed in the Seoul Center of the Korea Basic Science Institute. The fluorescence intensity was read with a microplate reader (BioTek, Winooski, VT, USA), and the stained cells were imaged by a fluorescence microscope (ECLIPSE Ni-U, Nikon Co., Tokyo, Japan).

\subsection{Metal Ion Release Test}

To measure the metal ions released from MOFs 1-3, $1 \mathrm{~mL}$ of deionized water or DPBS solution was added to $1 \mathrm{mg}$ of each MOF. Four samples of each MOF were prepared and stirred for $6,12,24$, and $48 \mathrm{~h}$ at $25^{\circ} \mathrm{C}$. After that time, each sample was centrifuged, and the supernatant was separated from each reaction tube. The amount of metal ions released in each sample was measured by ICP-MS. The degree of degradation was represented as the concentration of metal ions released into the medium in parts per million.

\subsection{Metabolic Viability}

The metabolic viability of the ovarian cancer SKOV3 cells, and two brain glioblastoma cell lines, U87 and LN229, was determined using alamar blue dye (DAL1025; Thermo Fisher Scientific, Waltham, MA, USA). Human dermal fibroblast (HDF) cells were used to represent normal cells in this assay. The cells were seeded in 96-well plates, keeping a cell density of $1 \times 10^{5}$ cells in a $100 \mu \mathrm{L}$ volume. Experiments were performed at $37^{\circ} \mathrm{C}$ in triplicate or more, with a metal-organic framework (MOF) with copper ( $\mathrm{Cu}-\mathrm{MOF})$, cobalt (Co-MOF), or zinc (Zn-MOF). The concentration of the MOF was selected as 1.6, 6.25, 12.5, 25,50 , and $100 \mu \mathrm{g} \mathrm{mL}^{-1}$. Conversion of the alamar blue dye was evaluated by determining the fluorescence emission using a BioTek plate reader, with the excitation at $540 \mathrm{~nm}$ and emission at $600 \mathrm{~nm}$.

\subsection{Flow Cytometric Analysis for Cell Death}

To determine the levels of cell death in SKOV3, U87, and LN229 cells treated with a $\mathrm{Cu}-\mathrm{MOF}$, cells were seeded and maintained at a cell density of $2 \times 10^{5}$ cells in each well of a 6-well plate. The cells were incubated with the $\mathrm{Cu}-\mathrm{MOF}$ for $24 \mathrm{~h}$, harvested, and stained with propidium iodide (PI; Sigma Aldrich, Darmstadt, Germany) and Annexin. The single-cell suspensions thus obtained were assessed and evaluated by flow cytometry. After $24 \mathrm{~h}$ of incubation with the Cu-MOF, cells were harvested, washed with cold PBS, and then centrifuged to form a pellet. The pellet was resuspended in PI and Annexin staining solution $\left(5 \mu \mathrm{g} \mathrm{mL} \mathrm{m}^{-1} \mathrm{PI}\right)$ and incubated for $15 \mathrm{~min}$ on ice. Immunogenic cell death was analyzed by a flow cytometer using the abovementioned procedure.

\subsection{Statistical Analysis}

All quantitative data $(n=4)$ are expressed as the mean \pm standard deviation (S.D.), and significant mean differences were estimated via Student's $t$-test. Statistical significance was set at $p<0.05,{ }^{* *} p<0.01$, and ${ }^{* * *} p<0.001$.

\section{Results and Discussion}

\subsection{Physical Characterizations of MOFs, 1-3}

Three MOFs, 1-3, containing glu and bpa ligands coordinated to copper, cobalt, and zinc were synthesized by various modified methods shown in Scheme 1 and Table 1 [43-45]. 


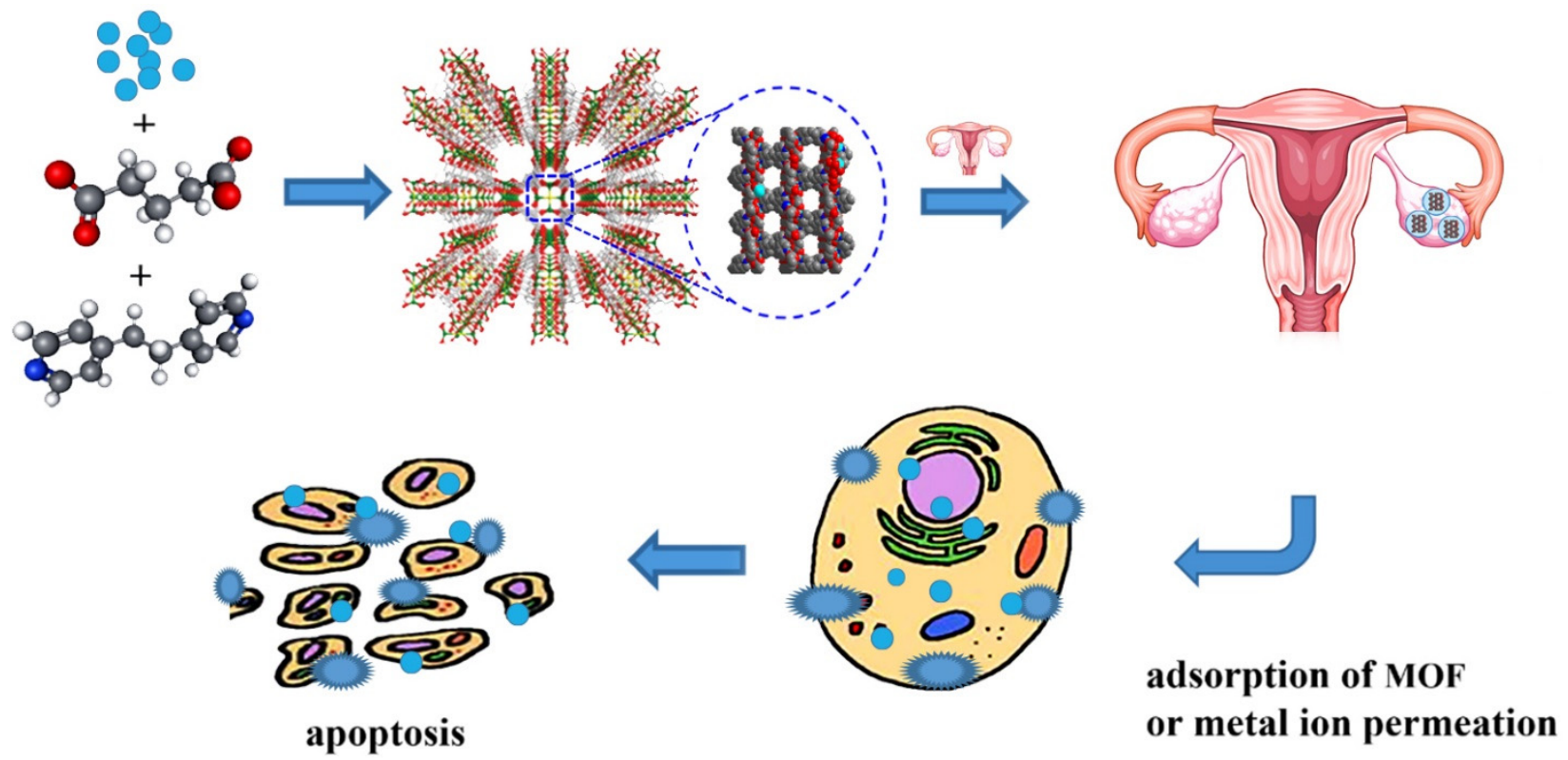

Scheme 1. The preparation of MOFs from metal salts, glutaric acid, and 1,2-bis(4-pyridyl)ethane: the apoptosis anticancer mechanism.

Table 1. Crystal data and structure refinement for the $\mathrm{Cu}-\mathrm{MOF}, \mathrm{Co}-\mathrm{MOF}$, and Zn-MOF.

\begin{tabular}{|c|c|c|c|}
\hline & $\mathrm{Cu}-\mathrm{MOF}$ & Co-MOF & Zn-MOF \\
\hline Empirical formula & $\mathrm{C}_{22} \mathrm{H}_{24} \mathrm{Cu}_{2} \mathrm{~N}_{2} \mathrm{O}_{8}$ & $\mathrm{C}_{34} \mathrm{H}_{44} \mathrm{Co}_{2} \mathrm{~N}_{4} \mathrm{O}_{8}$ & $\mathrm{C}_{22} \mathrm{H}_{28} \mathrm{~N}_{2} \mathrm{O}_{10} \mathrm{Zn}$ \\
\hline Formula weight & 571.51 & 723.34 & 611.20 \\
\hline Temperature & $223(2) \mathrm{K}$ & $296(2) \mathrm{K}$ & 293(2) K \\
\hline Wavelength & $0.71073 \AA$ & $0.71073 \AA$ & $0.71073 \AA$ \\
\hline Space group & $\mathrm{C} 2 / \mathrm{c}$ & $\mathrm{P} 21 / \mathrm{n}$ & $\mathrm{P} 21 / \mathrm{c}$ \\
\hline Unit cell dimensions & $\begin{array}{c}\mathrm{a}=24.848(7) \AA \\
\mathrm{b}=13.263(4) \AA \\
\mathrm{c}=8.675(2) \AA \\
\beta=92.745(3)^{\circ}\end{array}$ & $\begin{array}{l}\mathrm{a}=9.1670(3) \AA \\
\mathrm{b}=27.1849(8) \AA, \\
\mathrm{c}=13.5929(4) \AA, \\
\beta=95.6332(16)^{\circ}\end{array}$ & $\begin{array}{c}\mathrm{a}=11.025(2) \AA \\
\mathrm{b}=14.176(3) \AA \\
\mathrm{c}=16.191(3) \AA \\
\beta=95.50(3)^{\circ}\end{array}$ \\
\hline Volume & $2855.8(14) \AA^{3}$ & $3371.05(18) \AA^{3}$ & $2518.8(9) \AA^{3}$ \\
\hline $\mathrm{Z}$ & 4 & 4 & 4 \\
\hline Density (calculated) & $1.329 \mathrm{mg} / \mathrm{m}^{3}$ & $1.425 \mathrm{mg} / \mathrm{m}^{3}$ & $1.612 \mathrm{mg} / \mathrm{m}^{3}$ \\
\hline Independent reflections & $3231((\mathrm{int})=0.0484)$ & $5828(\mathrm{R}(\mathrm{int})=0.0387)$ & $4954(\mathrm{R}(\mathrm{int})=0.0252)$ \\
\hline Data/restraints/parameters & $3231 / 36 / 206$ & $5828 / 120 / 529$ & $4954 / 9 / 338$ \\
\hline Goodness of fit on F2 & 1.076 & 1.061 & 1.049 \\
\hline Final $R$ indices $[\mathrm{I}>2 \operatorname{sigma}(\mathrm{I})]$ & $\mathrm{R} 1=0.0569, \mathrm{wR} 2=0.1702$ & $\mathrm{R} 1=0.0757, \mathrm{wR} 2=0.1903$ & $\mathrm{R} 1=0.0621, \mathrm{wR} 2=0.1836$ \\
\hline
\end{tabular}

The nanoporous 3D Cu-MOF 1 was synthesized by a hydrothermal reaction [43] and formulated as $\left[\mathrm{Cu}_{2}(\mathrm{glu})_{2}(\mu-\mathrm{bpa})\right] \cdot 3\left(\mathrm{H}_{2} \mathrm{O}\right)$, which contains paddlewheel $\mathrm{Cu}_{2}$ dinuclear units bridged by glu ligands to form 2D sheets. These sheets were linked by bpa ligands to build a 3D framework composed of well-defined $1 \mathrm{D}$ channels with void volumes. The geometry of $\mathrm{Cu}$ (II) ions in the $\mathrm{Cu}-\mathrm{MOF}$ is a square pyramid coordinated with four equatorial $\mathrm{O}$ atoms of carboxylate and an axial $\mathrm{N}$ atom of bpa.

Co-MOF 2 was synthesized by a previously reported solvothermal reaction in DMF and water [44]. Glu ligands bridged $\mathrm{Co}^{\mathrm{II}}$ ions to form 2D sheets, and the sheets were bridged by bpa ligands to form an infinite 3D framework. This 3D framework was twofold interpenetrated, there was no significant void volume in the Co-MOF, and it was formulated as $\left[\mathrm{Co}_{2}(\mathrm{Glu})_{2}(\mathrm{bpa})\right] \cdot 4 \mathrm{H}_{2} \mathrm{O}$. The coordination geometry of the Co (II) ion is a distorted octahedral arrangement, constructed by one bridging carboxylate $\mathrm{O}$ atom, two chelating $\mathrm{O}$ atoms of carboxylate, one mono-dentate $\mathrm{O}$ atom of glu, and two $\mathrm{N}$ atoms of bpa. 
Zn-MOF 3 was previously prepared by the layer diffusion method [45], but it was more efficiently synthesized by hydrothermal reactions in this instance. Zn-MOF 3 was formulated as $\left[\left\{\mathrm{Zn}\left(\mathrm{H}_{2} \mathrm{O}\right)(\mathrm{Glu})\right\}_{2}(\mu\right.$-bpa $\left.)\right]$. Glu ligands bridge $\mathrm{Zn}(\mathrm{II})$ ions in asymmetric chelating and mono-dentate coordination modes, to form 1D chains that are further connected by bpa ligands to form a 2D sheet. In detail, water solvent molecules between sheets connect those undulated 2D sheets through hydrogen bonds to form a 3D-like framework. That is, the $\mathrm{Zn}$ (II) ion in the $\mathrm{Zn-MOF}$ is penta-coordinated, bound by two oxygen atoms from a chelating carboxylate, one oxygen atom from a mono-dentate carboxylate, one nitrogen atom from bpa, and one oxygen atom from water (Figure 1).
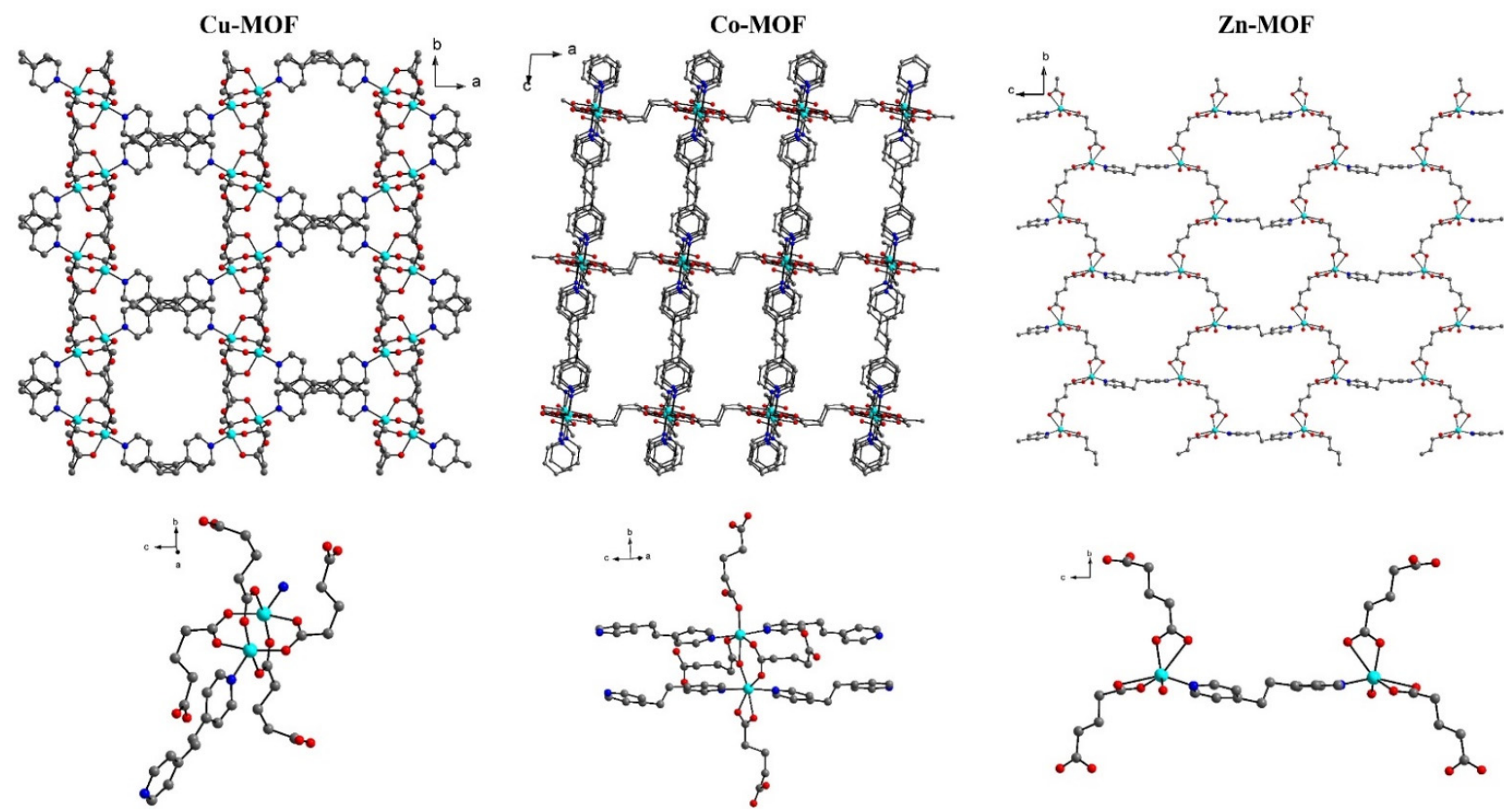

Figure 1. Crystal structures of the $\mathrm{Cu}-\mathrm{MOF}, \mathrm{Co}-\mathrm{MOF}$, and $\mathrm{Zn}-\mathrm{MOF}$ along the $\mathrm{b}$ axis with a 2D sheet (upper) and coordination environment around metal (II) centers $(\mathrm{Cu}, \mathrm{Co}$, and $\mathrm{Zn}$ ) (bottom). All hydrogens and disordered atoms are omitted for clarity. The color codes: green, metal $(\mathrm{Cu}, \mathrm{Co}$, and Zn); red, oxygen; blue, nitrogen; and grey, carbon.

The selective bond lengths for the three MOFs are summarized in Table 2. In detail, the metal-oxygen bond (M-O) increased in the order of $\mathrm{Zn}-\mathrm{O}(1.957(4) \AA)<\mathrm{Cu}-\mathrm{O}$

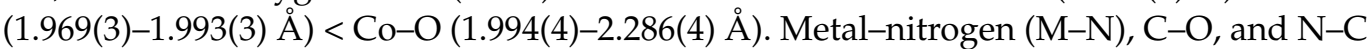
bonds also showed the same tendency as the M-O bond. That is, the Zn-MOF was composed of frameworks with stable bonds.

As shown in Figure 2, the purities of the as-prepared MOFs $\mathbf{1}-\mathbf{3}$ were confirmed by PXRD patterns. These patterns were in good agreement with the simulated patterns based on the X-ray crystallographic data.

Table 2. Selective bond lengths for the Cu-MOF, Co-MOF, and Zn-MOF.

\begin{tabular}{cccc}
\hline Bond & Cu-MOF & Co-MOF & Zn-MOF \\
\hline \multirow{2}{*}{$\mathrm{M}-\mathrm{O}$} & $\mathrm{Cu}-\mathrm{O}$ & $\mathrm{Co}-\mathrm{O}$ & $\mathrm{Zn}-\mathrm{O}$ \\
& $1.969(3)-1.993(3) \AA$ & $1.994(4)-2.285(4) \AA$ & $1.957(4) \AA$ \\
$\mathrm{M}-\mathrm{N}$ & $\mathrm{Cu}-\mathrm{N}$ & $\mathrm{Co}-\mathrm{N}$ & $\mathrm{Zn}-\mathrm{N}$ \\
$\mathrm{C}-\mathrm{O}$ & $2.117(11)-2.193(3) \AA$ & $2.150(3)-2.184(3) \AA$ & $2.048(4), 2.056(4) \AA$ \\
$\mathrm{N}-\mathrm{C}$ & $1.239(6)-1.254(5) \AA$ & $1.239(7)-1.261(7) \AA$ & $1.213(7)-1.246(6) \AA$ \\
& 1.390 & $1.387(2)-1.432(13) \AA$ & $1.316(7)-1.330(7) \AA$ \\
\hline
\end{tabular}


Cu-MOF

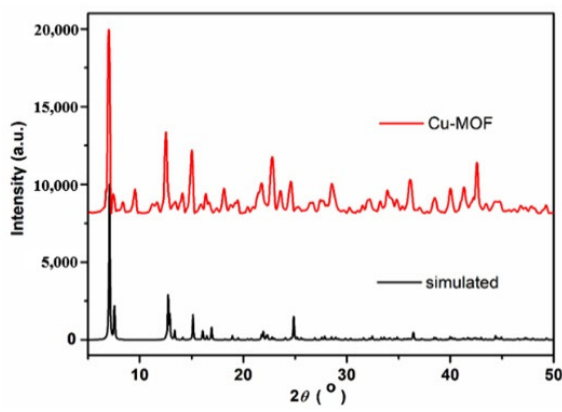

Co-MOF

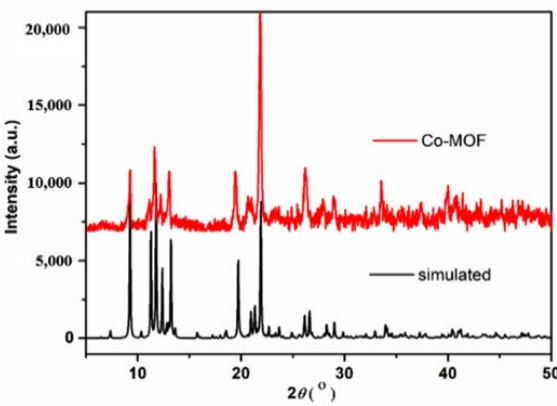

Zn-MOF

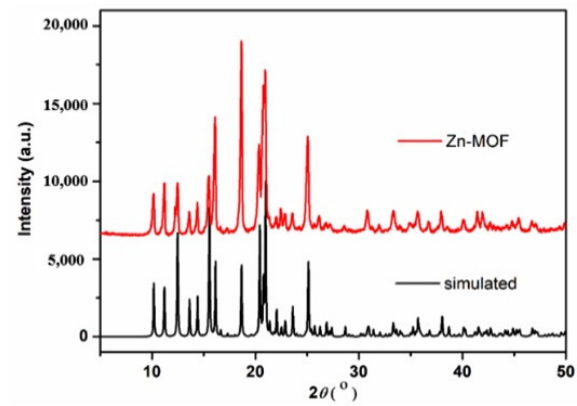

Figure 2. PXRD patterns of the Cu-MOF, Co-MOF, and Zn-MOF: simulated (black) and as-prepared (red).

Furthermore, the FT-IR spectra of the three MOFs showed the characteristic C-O symmetric and asymmetric stretching bands at $1450-1600 \mathrm{~cm}^{-1}$ representing the carbonyl groups of glutarate ligands coordinated to the MOFs (Figure 3).

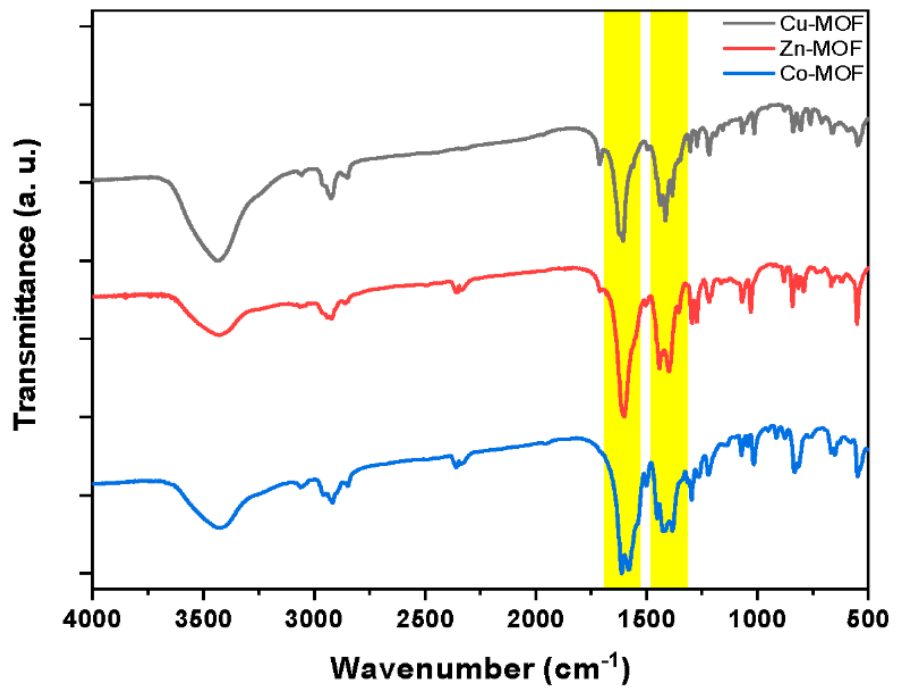

Figure 3. FT-IR spectra of the Cu-MOF (black), Co-MOF (blue), and Zn-MOF (red).

\subsection{The Degradability of MOFs in Physiological Media}

To investigate the participation of metal ions released from the three MOFs in the anticancer mechanism in physiological media, the MOFs were immersed in deionized water or Dulbeccos's PBS solution (DPBS) for one day, and then their stabilities were measured by PXRD, SEM, and ICP-MS.

At first, the crystalline natures of the as-prepared MOFs were compared with those of the samples immersed in deionized water or Dulbeccos's PBS (DPBS) using PXRD. The PXRD patterns of the Cu-MOF immersed in deionized water or DPBS solution did not present any distinguished difference from the as-prepared $\mathrm{Cu}-\mathrm{MOF}$, as shown in Figure 4. The PXRD patterns of two samples were in line with the as-prepared pattern, which indicated that the initial crystal structure was maintained after immersion in deionized water or DPBS. However, a new peak at $22.5^{\circ}$ was observed after immersion in DPBS, which may be derived from the interaction of $\mathrm{Cu}$ (II) ions on the surface of the MOF with phosphate ions within the DPBS, while the initial crystalline structure was still maintained [46,47]. As a result, the $\mathrm{Cu}-\mathrm{MOF}$ was expected to be considerably stable in an aqueous solution for one day. 
Cu-MOF

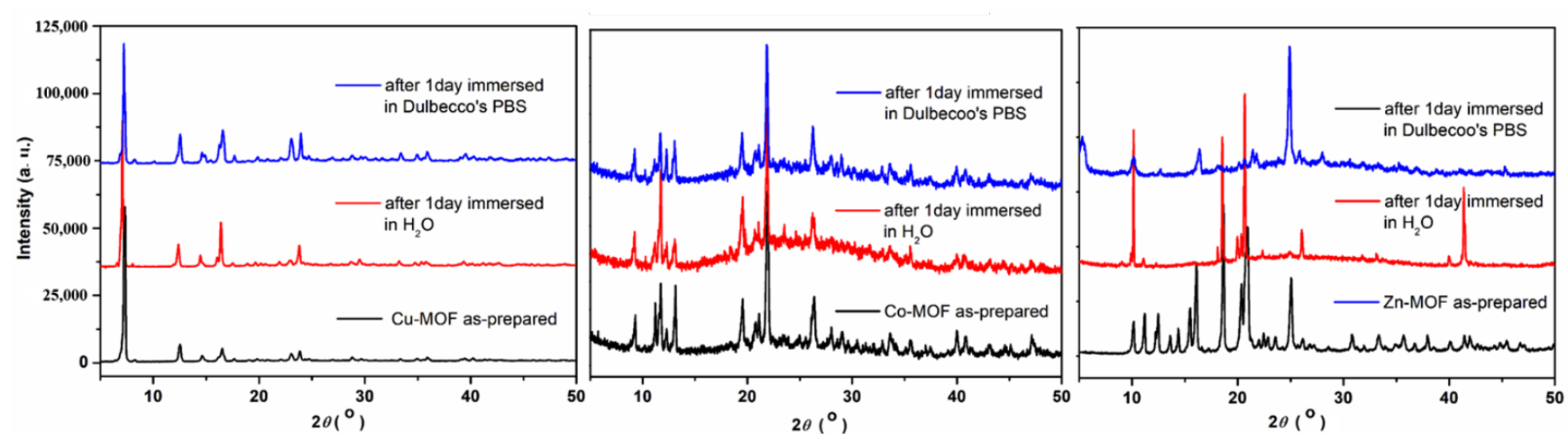

Figure 4. PXRD patterns of the Cu-MOF, Co-MOF, and Zn-MOF: as-prepared (black), and after immersion in $\mathrm{H}_{2} \mathrm{O}$ (red) or Dulbecco's PBS (blue).

In the case of the Co-MOF immersed in deionized water or DPBS solution (DPBS) for one day, the initial PXRD patterns of the Co-MOF were maintained without newly appearing peaks.

However, a sharp peak appeared at $41^{\circ}$ on the Zn-MOF immersed in deionized water for one day, while the Zn-MOF was stable in DPBS solution (DPBS).

The morphological changes of the MOFs before and after immersion in deionized water or DPBS for one day were observed using SEM. As shown in Figure 5a, the asprepared $\mathrm{Cu}-\mathrm{MOF}$ was obtained as a large crystal. The $\mathrm{Cu}-\mathrm{MOF}$ was broken into small pieces after immersion in deionized water for one day, but no changes on the surface were observed (Figure 5b). In the case of DPBS, the size of the Cu-MOF was maintained, but flower-like structures were newly formed on the surface (Figure $5 \mathrm{c}$ ). This interesting phenomenon may be attributed to a reaction between $\mathrm{Cu}$ (II) ions on the surface and the phosphate $\left(\mathrm{PO}_{4}{ }^{3-}\right)$, hydrophosphate $\left(\mathrm{HPO}_{4}{ }^{2-}\right)$, or dihydrophosphate anions $\left(\mathrm{H}_{2} \mathrm{PO}_{4}{ }^{-}\right)$ within PBS, which did not affect the crystal framework [48].

The crystal morphology of the Co-MOF immersed in deionized $\mathrm{H}_{2} \mathrm{O}$ showed a remarkable difference, that is, a partially dissolved shape compared to the as-prepared Co-MOF. In contrast, when it was immersed in DPBS solution for one day, its surface transformed to small flower-type shapes with various sizes. This result also suggests that phosphate anions partially coated the surface of the Co-MOF.

The $\mathrm{Zn}-\mathrm{MOF}$ showed the same tendency for the size effect as the $\mathrm{Cu}-\mathrm{MOF}$, but flowers composed of long petals coated its surface after immersion in DPBS (Figure 5c).

To study the degree of degradability, the amount of $\mathrm{Cu}$ (II) ions released from the $\mathrm{Cu}-\mathrm{MOF}$ was quantitatively measured using ICP-MS (Figure 6). After immersion of $1 \mathrm{mg}$ of sample in $1 \mathrm{~mL}$ of deionized water for $24 \mathrm{~h}$ and $48 \mathrm{~h}$, the amount of released $\mathrm{Cu}$ (II) ions was measured. $\mathrm{Cu}$ (II) ions were released at concentrations of $5.0 \mu \mathrm{g} \mathrm{mL}-1$ and $3.6 \mu \mathrm{g} \mathrm{mL} \mathrm{m}^{-1}$ after $24 \mathrm{~h}$ and $48 \mathrm{~h}$, respectively. On the other hand, the concentrations of $\mathrm{Cu}$ (II) ions released in DPBS for the same duration were only 0.1 and $0.7 \mu \mathrm{g} \mathrm{mL}^{-1}$, which were negligible compared to those in deionized water. Thus, due to the flower-like coating on the surface, the $\mathrm{Cu}-\mathrm{MOF}$ continued to stay stable for $48 \mathrm{~h}$ in the physiological medium. These results agree well with the SEM images.

The Co-MOF released Co (II) ions at a concentration of $174.8 \mu \mathrm{g} \mathrm{mL}^{-1}$ for $48 \mathrm{~h}$ in deionized water. However, the amount of Co (II) ions significantly reduced by $48 \mathrm{~h}$ to $8.1 \mu \mathrm{g} \mathrm{mL} \mathrm{m}^{-1}$ in DPBS.

In the case of the $\mathrm{Zn}-\mathrm{MOF}$, it released metal ions at $89.7 \mu \mathrm{g} \mathrm{mL} \mathrm{L}^{-1}$ for $24 \mathrm{~h}$ and then $70.3 \mu \mathrm{g} \mathrm{mL} \mathrm{m}^{-1}$ after $48 \mathrm{~h}$ in deionized water. The $\mathrm{Zn}-\mathrm{MOF}$ was stable, comparable to the Cu-MOF in DPBS.

These results show that the $\mathrm{Cu}-\mathrm{MOF}$ and the $\mathrm{Zn}$-MOF were considerably stable in physiological media, more so than the Co-MOF, and suggest the possibility of a Cu-MOF directly contacting bacteria or cancer cells, resulting in cell death. Further, the high stability 
of all MOFs is expected to have a positive effect on biocompatibility due to the low release of metal ions.

(a)

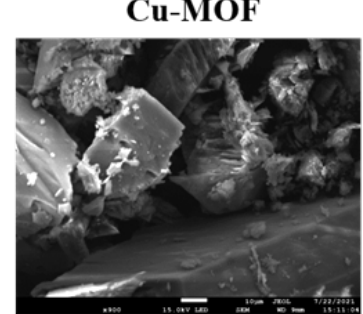

(b)

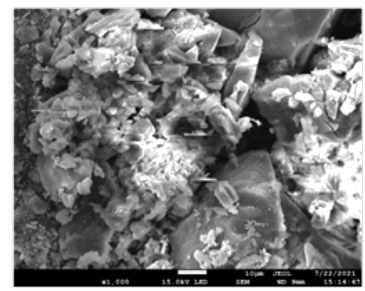

(c)

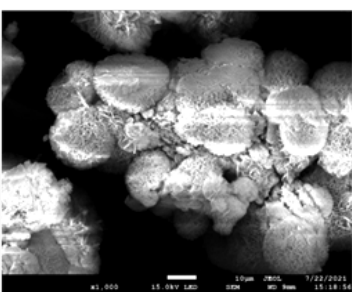

Co-MOF
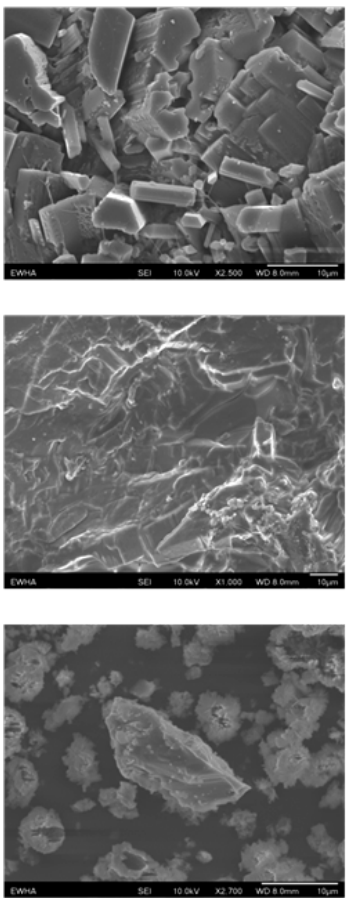

Zn-MOF
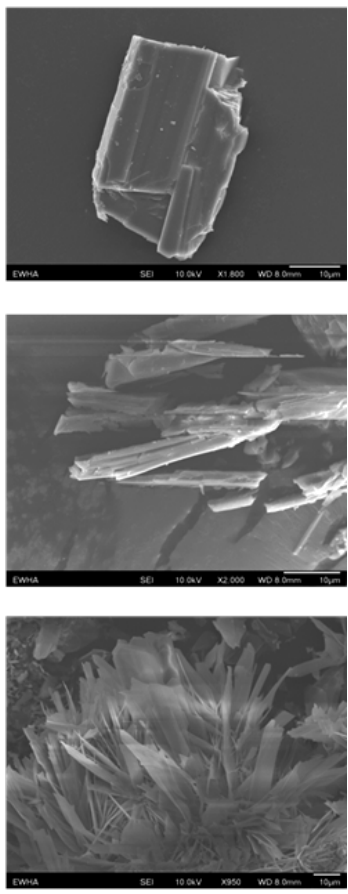

Figure 5. SEM images of (a) as-prepared MOFs, (b) MOFs after immersion in $\mathrm{H}_{2} \mathrm{O}$ for 1 day, and (c) MOFs after immersion in Dulbecco's PBS for 1 day; MOFs: Cu-MOF, Co-MOF, and Zn-MOF (scale bar: $10 \mu \mathrm{m})$.
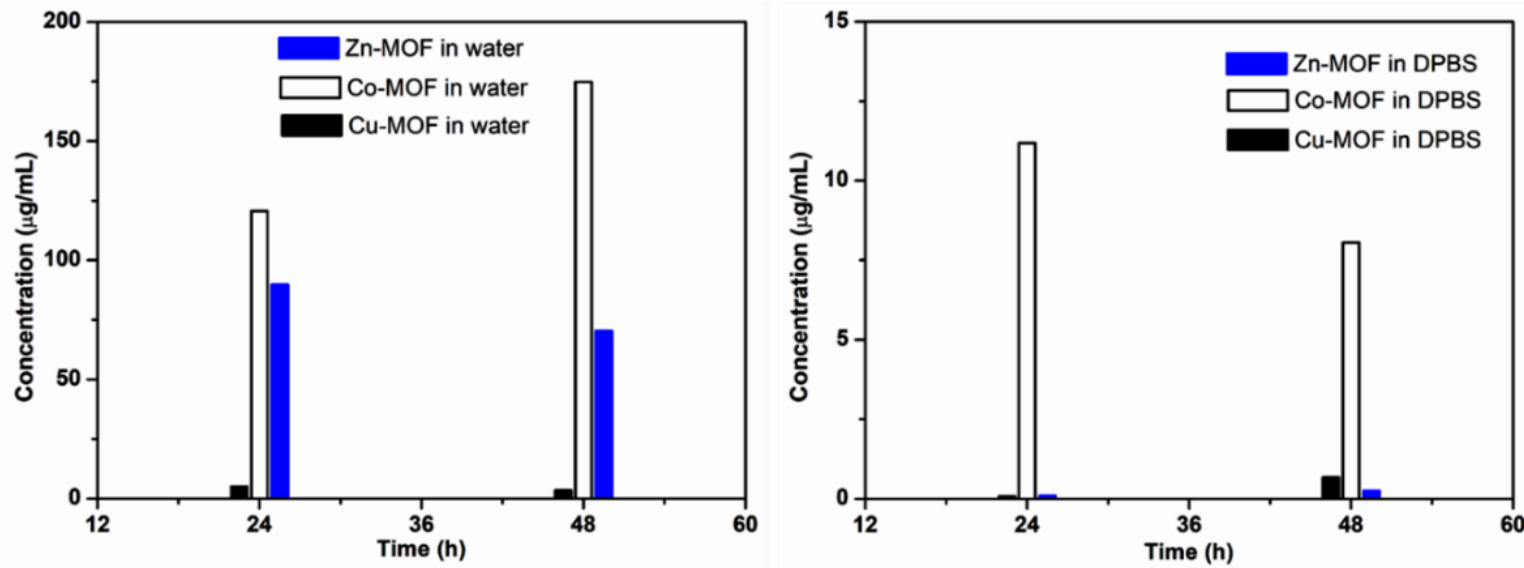

Figure 6. Metal (II) ions released from each MOF after immersion in deionized water (left) and DPBS (right) for $24 \mathrm{~h}$ and $48 \mathrm{~h}$, as determined by ICP-MS.

\subsection{Effect of MOF on Cell Viability and Cytotoxicity}

In this work, the anticancer activity of MOFs in ovarian cancer SKOV3 cells and dermal HDF cells was detected using alamar blue dye following incubation with a MOF for $24 \mathrm{~h}$. The cell viability was attained using alamar blue dye. The concentration-dependent behaviors of SKOV3 were evaluated after $24 \mathrm{~h}$ incubation with the Co-MOF, Zn-MOF, and $\mathrm{Cu}-\mathrm{MOF}$, as shown in Figure 7. Based on the obtained results, the $\mathrm{Cu}-\mathrm{MOF}$ showed a higher anticancer activity in SKOV3 cells compared to the $\mathrm{Zn}-\mathrm{MOF}$ and Co-MOF. The cell viability continued to decrease as the concentration of the $\mathrm{Cu}-\mathrm{MOF}$ increased. A high concentration of the $\mathrm{Cu}-\mathrm{MOF}$ led to a significantly lower viability than the control. Notably, 
no significant changes were observed in the Co-MOF and Zn-MOF, as shown in Figure 7. For the safety assessment, we performed the cytotoxic test on HDF cells. In these results, no significant differences were observed between the three MOFs following exposure in $1 \mathrm{mg} \mathrm{mL}^{-1}$, representing a relatively high concentration (Figure 7). This could guarantee the safe treatment of cancer patients in the future. The $\mathrm{Cu}-\mathrm{MOF}$ was selected for further investigations on U87 and LN229 cells with varying concentrations $\left(1,10,100 \mu \mathrm{g} \mathrm{mL} L^{-1}\right)$ of the Cu-MOF. The U87 and LN229 cells showed a significant decrease at $100 \mu \mathrm{g} \mathrm{mL}{ }^{-1}$ of the $\mathrm{Cu}-\mathrm{MOF}$ after $24 \mathrm{~h}$ incubation, as shown in Figure 8.
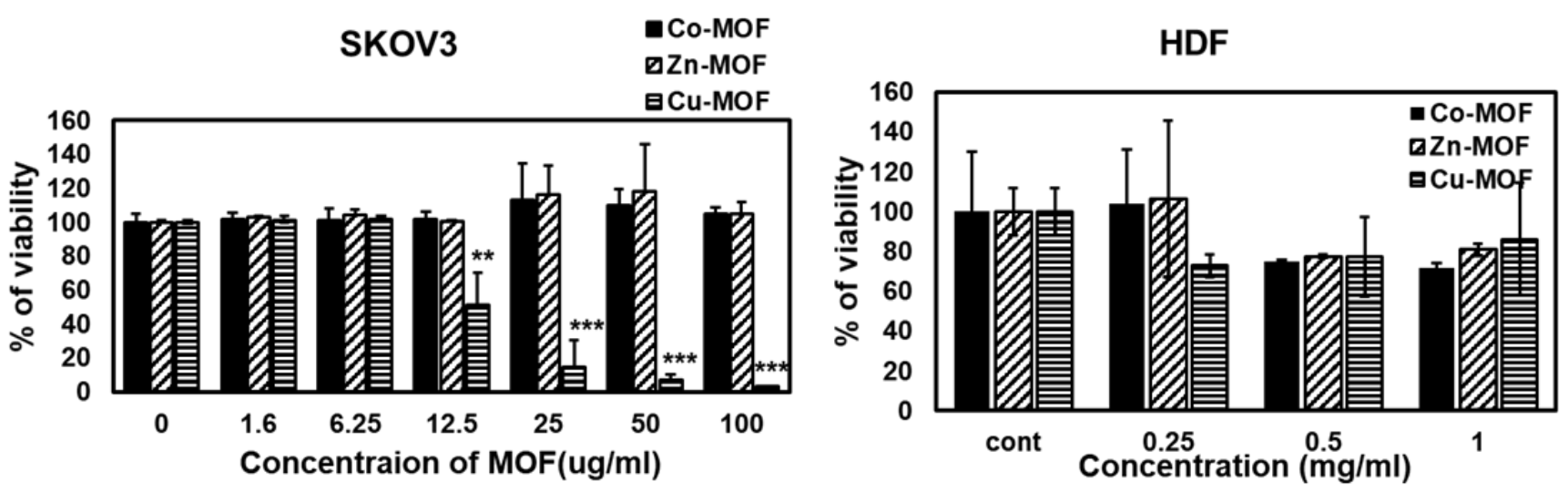

Figure 7. In vitro anticancer activity and cytotoxicity of MOFs in human ovarian cancer SKOV3 cells and human dermal fibroblast (HDF) cells. Cell viability in each sample was detected using alamar blue dye following incubation with a MOF for $24 \mathrm{~h}$. All values are presented as means $\pm \mathrm{SD}$ of three independent experiments. ${ }^{* *} p<0.01$, and ${ }^{* * *} p<0.001$.

U87

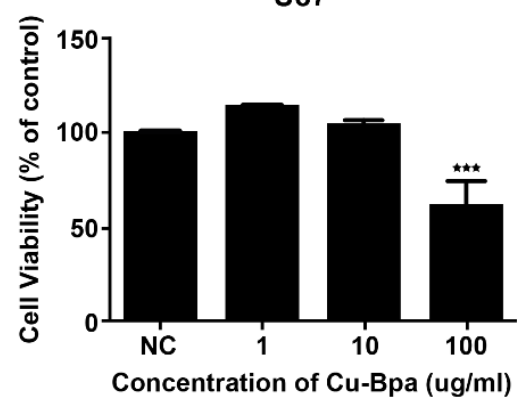

LN229

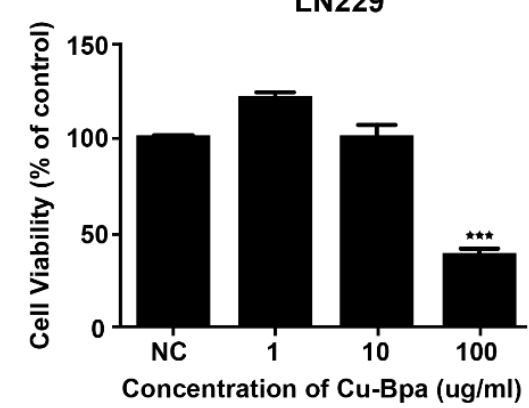

SKOV3

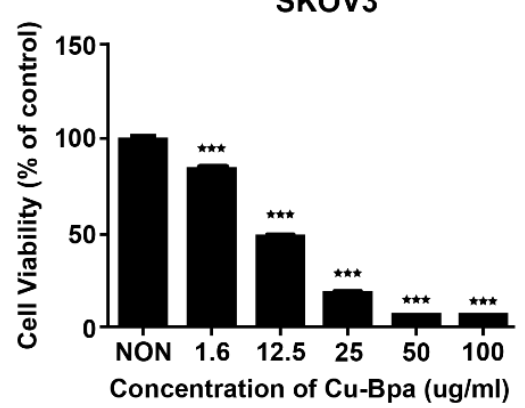

Figure 8. In vitro anticancer activity of MOFs in glioblastoma U87G and LN229 cells, and ovarian cancer SKOV3 cells. Cell viability in each sample was detected using alamar blue dye following incubation with a MOF for $24 \mathrm{~h}$. All values are presented as means \pm SD of three independent experiments. ${ }^{* * *} p<0.001$.

We have previously investigated the occurrence of ROS due to metal ions and the oxidative reaction with the cell membrane of the bacteria [43]. In the previous study, we proposed the main cause of cell membrane collapse might be derived from the combination of radicals and hydrogen ions in the cell membrane to eliminate hydrogen ions from the cell membrane. Combined with cytotoxicity and apoptosis assays, where the MOFs were treated and reacted under physiological conditions at $37{ }^{\circ} \mathrm{C}$ in a $\mathrm{CO}_{2}$ incubator, the reduction cycle between $\mathrm{Cu}^{2+}$ and $\mathrm{Cu}^{+}$on the surface of the $\mathrm{Cu}-\mathrm{MOF}$ attached to cell membranes was accelerated, and the pathways that produce reactive oxygen species (ROS) changed, increasing ROS to a level that causes cytotoxicity to cancer cells and improvement of the $\mathrm{IC}_{50}$ [42,49]. Taken together, these results demonstrate the wellestablished phenomenon of $\mathrm{Cu}-\mathrm{MOF}$-activated $\mathrm{ROS}$ generation via chemical reaction in an aqueous solution, inactivating cancer cells, such as U87MG, LN229, and SKOV3, as well as 
E. coli, S. aureus, P. pneumoniae, and P. aeruginosa and MRSA. Therefore, the Cu-MOF has a good stability and reusability suitable for biomedical applications.

\subsection{Cell Death Analysis}

The effect of the Cu-MOF on cell death in SKOV3, U87, and LN229 cells was observed. To investigate whether the Cu-MOF led to the death of SKOV3, U87, and LN229 cells, the cells were seeded in a 6-well plate and then incubated with the Cu-MOF for $24 \mathrm{~h}$. The cell death induced by the Cu-MOF within $24 \mathrm{~h}$ of incubation was determined by the uptake of the PI solution, which is indicative of a dysfunctional plasma membrane of cells. As shown in Figure 9, the scatter plot indicated no changes in the control (without a Cu-MOF) in SKOV3, U87, and LN229 cells. On the other hand, significant apoptotic cell death was observed in cancer cells with a MOF at the concentration of $12.5 \mu \mathrm{g} \mathrm{mL}^{-1}$, as shown in Figure 9 .

U87
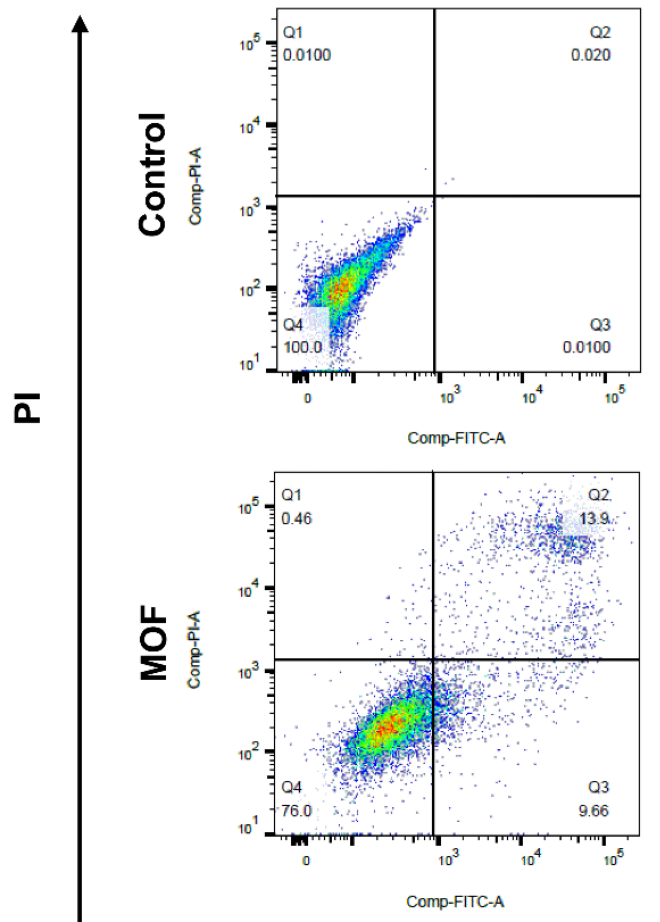
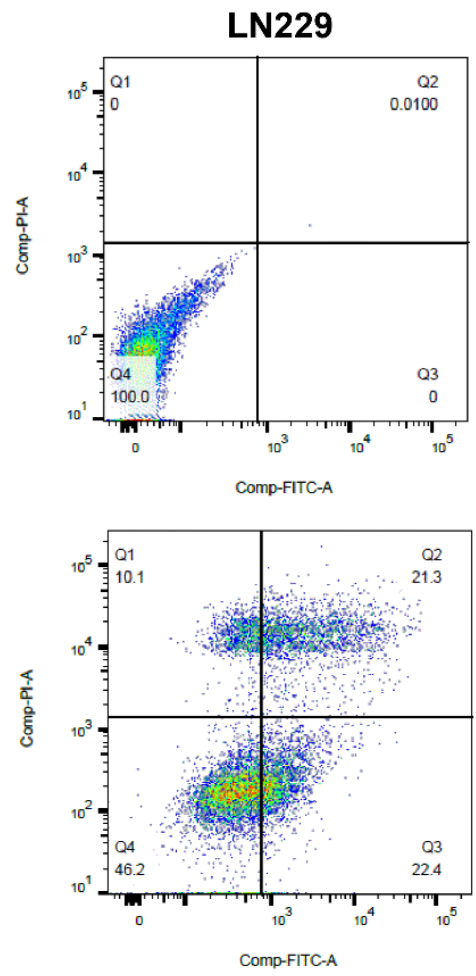

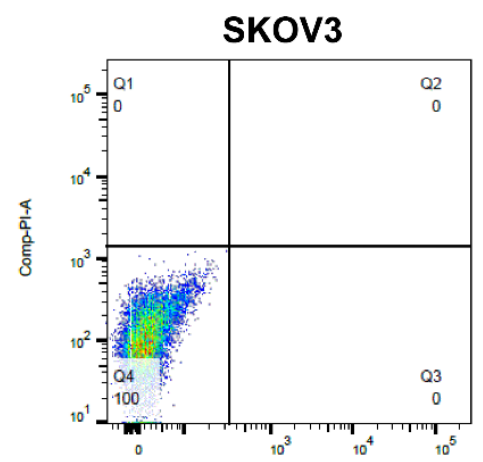

Comp-FITC-A

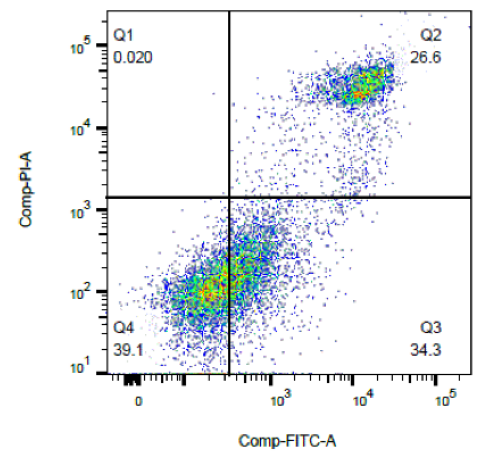

Annexin V

Figure 9. Apoptotic cell death induced by the Cu-MOF in cancer cells; $12.5 \mu \mathrm{g} \mathrm{mL}^{-1}\left(\mathrm{IC}_{50}\right)$ of Cu-MOF.

In conclusion, the three MOFs had different structures in terms of bond strength, porosity, and dimension. Their bioactivity increased comparatively with their stability; meanwhile, cytotoxicity decreased as the released metal ion amount increased. Interestingly, the anticancer property was the best on the robust $\mathrm{Cu}-\mathrm{MOF}$. The $\mathrm{Cu}$ metal ions on the surface of the MOF are supposed to have a greater impact on cell membranes compared to Co (II) or Zn (II) ions. This result shows that the unique natures of metal ions bonded onto the surface of a framework are very important for the viability of cancer cells.

\subsection{Summary}

Three MOFs composed of $\mathrm{Cu}, \mathrm{Co}$, and $\mathrm{Zn}$ were prepared by a modified solvothermal reaction under high pressure. Their structures were determined by single-crystal crystallography. Their stabilities in physiological media were investigated by PXRD, SEM, and 
ICP-MS. Although the Cu-MOF was very stable in physiological media, it showed a high anticancer activity toward ovarian cancer cells due to the unique nature of $\mathrm{Cu}$ (II) ions on the surface of the MOF, such as the occurrence of ROS due to metal ions resulting from the redox reaction with the cell membranes of cancer cells; where SKOV3 cells were treated with a low concentration of the $\mathrm{Cu}-\mathrm{MOF}$, the $\mathrm{IC}_{50}$ value was measured by $12.5 \mu \mathrm{mol} \cdot \mathrm{mL}^{-1}$ of the $\mathrm{Cu}-\mathrm{MOF}$. Further, this study shows that the cancer cell death mechanisms induced by the Cu-MOF were mediated by apoptosis. We expect this research to be valuable in developing a MOF which satisfies both biocompatibility and a therapeutic effect toward cancer, inspiring the design of various functional MOFs suitable for cancer therapy.

Author Contributions: Conceptualization, D.N.L.; methodology, I.H. and S.A.C.; validation, I.H. and S.A.C.; formal analysis, I.H. and S.A.C.; investigation, I.H. and S.A.C.; data curation, I.H. and S.A.C.; writing—original draft preparation, D.N.L. and I.H.; writing—review and editing, I.H. and D.N.L.; supervision, D.N.L.; funding acquisition, I.H. and D.N.L. All authors have read and agreed to the published version of the manuscript.

Funding: This research was supported by the Basic Science Research Program of the National Research Foundation of Korea (2021R1A2C1004285, 2020R1I1A1A01073071).

Institutional Review Board Statement: Not applicable.

Informed Consent Statement: Not applicable.

Data Availability Statement: Not applicable.

Acknowledgments: We cordially thank the Nano-Material Technology Development Program through the National Research Foundation of Korea (NRF) funded by the Ministry of Science, ICT and Future Planning (2009-0082580), and the research support project of Kwangwoon University in the year 2021.

Conflicts of Interest: The authors declare no competing financial interests.

\section{References}

1. Bray, F.; Ferlay, J.; Soerjomataram, I.; Siegel, R.L.; Torre, L.A.; Jemal, A. Global cancer statistics 2018: GLOBOCAN estimates of incidence and mortality worldwide for 36 cancers in 185 countries. CA Cancer J. Clin. 2018, 68, 394-424. [CrossRef]

2. Ibrahim, M.; Sabouni, R.; Husseini, G.A. Anti-cancer Drug Delivery Using Metal Organic Frameworks (MOFs). Curr. Med. Chem. 2017, 24, 193-214. [CrossRef] [PubMed]

3. DeVita, V.T., Jr.; Chu, E. A history of cancer chemotherapy. Cancer Res. 2008, 68, 8643-8653. [CrossRef] [PubMed]

4. Abazari, R.; Mahjoub, A.R.; Slawin, A.M.; Carpenter-Warren, C.L. Morphology- and size-controlled synthesis of a metal-organic framework under ultrasound irradiation: An efficient carrier for $\mathrm{pH}$ responsive release of anti-cancer drugs and their applicability for adsorption of amoxicillin from aqueous solution. Ultrason. Sonochem. 2018, 42, 594-608. [CrossRef]

5. Yang, Z.; Guo, F.; Albers, A.E.; Sehouli, J.; Kaufmann, A.M. Disulfiram modulates ROS accumulation and overcomes synergistically cisplatin resistance in breast cancer cell lines. Biomed. Pharmacother. 2019, 113, 108727. [CrossRef] [PubMed]

6. Lee, D.N.; Han, I.; Choi, S.A. Metal organic frameworks compound and anticancer agents with that. KR Patent No. 1022642410000, 2021.

7. Lattuada, E.; Leo, M.; Caprara, D.; Salvatori, L.; Stoppacciaro, A.; Sciortino, F.; Filetici, P. DNA-GEL, Novel Nanomaterial for Biomedical Applications and Delivery of Bioactive Molecules. Front. Pharmacol. 2020, 11, 01345. [CrossRef] [PubMed]

8. Liu, W.; Zhong, Y.; Wang, X.; Zhuang, C.; Chen, J.; Liu, D.; Xiao, W.; Pan, Y.; Huang, J.; Liu, J. A porous Cu(II)-based metal-organic framework carrier for $\mathrm{pH}$-controlled anticancer drug delivery. Inorg. Chem. Commun. 2020, 111, 107675. [CrossRef]

9. Kosower, N.S.; Kosower, E.M. The Glutathione Status of Cells. Int. Rev. Cytol. 1978, 54, 109-160. [PubMed]

10. Hall, M.D.; Hambley, T.W. Platinum(IV) Antitumour Compounds: Their Bioinorganic Chemistry. Coord. Chem. Rev. 2002, 232, 49-67. [CrossRef]

11. Cheng, L.; Wang, C.; Feng, L.; Yang, K.; Liu, Z. Functional Nanomaterials for Phototherapies of Cancer. Chem. Rev. 2014, 114, 10869-10939. [CrossRef]

12. Liang, C.; Xu, L.; Song, G.; Liu, Z. Emerging Nanomedicine Approaches Fighting Tumor Metastasis: Animal Models, MetastasisTargeted Drug Delivery, Phototherapy, and Immunotherapy. Chem. Soc. Rev. 2016, 45, 6250-6269. [CrossRef]

13. Zhang, W.; Lu, J.; Gao, X.; Li, P.; Zhang, W.; Ma, Y.; Wang, H.; Tang, B. Enhanced Photodynamic Therapy by Reduced Levels of Intracellular Glutathione Obtained By Employing a Nano-MOF with CuII as the Active Center. Angew. Chem. 2018, 130, 4985-4990. [CrossRef]

14. Cui, Y.; Yue, Y.; Qian, G.; Chen, B. Luminescent Functional Metal-Organic Frameworks. Chem. Rev. 2012, 112, 1126-1162. [CrossRef] 
15. Wang, C.; Zhang, T.; Lin, W. Rational Synthesis of Noncentrosymmetric Metal-Organic Frameworks for Second-Order Nonlinear Optics. Chem. Rev. 2012, 112, 1084-1104. [CrossRef]

16. Park, J.; Jiang, Q.; Feng, D.; Mao, L.; Zhou, H.-C. Size-Controlled Synthesis of Porphyrinic Metal-Organic Framework and Functionalization for Targeted Photodynamic Therapy. J. Am. Chem. Soc. 2016, 138, 3518-3525. [CrossRef] [PubMed]

17. Lu, K.; He, C.; Lin, W. Nanoscale Metal-Organic Framework for Highly Effective Photodynamic Therapy of Resistant Head and Neck Cancer. J. Am. Chem. Soc. 2014, 136, 16712-16715. [CrossRef] [PubMed]

18. Wang, Y.; Wu, W.; Liu, J.; Manghnani, P.N.; Hu, F.; Ma, D.; Teh, C.; Wang, B.; Liu, B. Cancer-Cell-Activated Photodynamic Therapy Assisted by $\mathrm{Cu}(\mathrm{II})$-Based Metal-Organic Framework. ACS Nano 2019, 13, 6879-6890. [CrossRef] [PubMed]

19. Li, Y.; Lu, A.; Long, M.; Cui, L.; Chen, Z.; Zhu, L. Nitroimidazole derivative incorporated liposomes for hypoxia-triggered drug delivery and enhanced therapeutic efficacy in patient-derived tumor xenografts. Acta Biomater. 2019, 83, 334-348. [CrossRef] [PubMed]

20. Mousavikhamene, Z.; Abdekhodaie, M.J.; Ahmadieh, H. Facilitation of transscleral drug delivery by drug loaded magnetic polymeric particles. Mater. Sci. Eng. C 2017, 79, 812-820. [CrossRef] [PubMed]

21. Leong, J.; Chin, W.; Ke, X.; Gao, S.; Kong, H.; Hedrick, J.L.; Yang, Y.Y. Disease-directed design of biodegradable polymers: Reactive oxygen species and pH-responsive micellar nanoparticles for anticancer drug delivery. Nanomedicine 2018, 14, $2666-2677$. [CrossRef] [PubMed]

22. Cai, H.; Huang, Y.-L.; Li, D. Biological Metal-Organic Frameworks: Structures, Host-Guest Chemistry and Bio-Applications. Coord. Chem. Rev. 2019, 378, 207-221. [CrossRef]

23. An, H.; Li, M.; Gao, J.; Zhang, Z.; Ma, S.; Chen, Y. Incorporation of Biomolecules in Metal-Organic Frameworks for Advanced Applications. Coord. Chem. Rev. 2019, 384, 90-106. [CrossRef]

24. Abánades Lázaro, I.; Forgan, R.S. Application of Zirconium MOFs in Drug Delivery and Biomedicine. Coord. Chem. Rev. 2019, 380, 230-259. [CrossRef]

25. Zhang, Z.; Sang, W.; Xie, L.; Dai, Y. Metal-Organic Frameworks for Multimodal Bioimaging and Synergistic Cancer Chemotherapy. Coord. Chem. Rev. 2019, 399, 213022. [CrossRef]

26. Wang, H.-S. Metal-Organic Frameworks for Biosensing and Bioimaging Applications. Coord. Chem. Rev. 2017, 349, 139-155. [CrossRef]

27. Horcajada, P.; Serre, C.; Vallet-Regí, M.; Sebban, M.; Taulelle, F.; Férey, G. Metal-organic frameworks as efficient materials for drug delivery. Angew.Chem. Int. Ed. 2006, 118, 6120-6124. [CrossRef]

28. Aguilera-Sigalat, J.; Bradshaw, D. Synthesis and Applications of Metal-Organic Framework-Quantum Dot (QD@MOF) Composites. Coord. Chem. Rev. 2016, 307, 267-291. [CrossRef]

29. Yang, J.-C.; Chen, Y.; Li, Y.-H.; Yin, X.-B. Magnetic Resonance Imaging-Guided Multi-Drug Chemotherapy and Photothermal Synergistic Therapy with $\mathrm{pH}$ and NIR-Stimulation Release. ACS Appl. Mater. Interfaces 2017, 9, 22278-22288. [CrossRef]

30. Liu, W.; Wang, Y.-M.; Li, Y.-H.; Cai, S.-J.; Yin, X.-B.; He, X.-W.; Zhang, Y.K. Fluorescent Imaging-Guided Chemotherapy-andPhotodynamic Dual Therapy with Nanoscale Porphyrin Metal-Organic Framework. Small 2017, 13, 1603459. [CrossRef]

31. Yang, J.; Yang, Y.W. Metal-Organic Frameworks for Biomedical Applications. Small 2020, 16, e1906846. [CrossRef] [PubMed]

32. Giliopoulos, D.; Zamboulis, A.; Giannakoudakis, D.; Bikiaris, D.; Triantafyllidis, K. Polymer/Metal Organic Framework (MOF) Nanocomposites for Biomedical Applications. Molecules 2020, 25, 185. [CrossRef]

33. Chedid, G.; Yassin, A. Recent Trends in Covalent and Metal Organic Frameworks for Biomedical Applications. Nanomaterials 2018, 8, 916. [CrossRef] [PubMed]

34. Lu, K.; Aung, T.; Guo, N.; Weichselbaum, R.; Lin, W. Nanoscale Metal-Organic Frameworks for Therapeutic, Imaging, and Sensing Applications. Adv. Mater. 2018, 30, e1707634. [CrossRef] [PubMed]

35. Jo, J.H.; Kim, H.-C.; Huh, S.; Kim, Y.; Lee, D.N. Antibacterial activities of Cu-MOFs containing glutarates and bipyridyl ligands. Dalton Trans. 2019, 48, 8084-8093. [CrossRef]

36. Motakef-Kazemi, N.; Shojaosadati, S.A.; Morsali, A. In situ synthesis of a drug-loaded MOF at room temperature. Microporous Mesoporous Mater. 2014, 186, 73-79. [CrossRef]

37. Oh, H.; Li, T.; An, J. Drug Release Properties of a Series of Adenine-Based Metal-Organic Frameworks. Chem.—Eur. J. 2015, 21, 17010-17015. [CrossRef]

38. Taylor-Pashow, K.M.; Della Rocca, J.; Xie, Z.; Tran, S.; Lin, W. Postsynthetic modifications of iron-carboxylate nanoscale metalorganic frameworks for imaging and drug delivery. Am. Chem. Soc. 2009, 131, 14261-14263. [CrossRef]

39. Bellido, E.; Hidalgo, T.; Lozano, M.V.; Guillevic, M.; Simón-Vázquez, R.; Santander-Ortega, M.J.; Gonzalez-Fernandez, A.; Serre, C.; Alonso, M.J.; Horcajada, P. Heparin-engineered mesoporous iron metal-organic framework nanoparticles: Toward stealth drug nanocarriers. Adv. Healthc. Mater. 2015, 4, 1246-1257. [CrossRef]

40. Ding, N.; Li, H.; Feng, X.; Wang, Q.; Wang, S.; Ma, L.; Zhou, J.; Wang, B. Partitioning MOF-5 into confined and hydrophobic compartments for carbon capture under humid conditions. J. Am. Chem. Soc. 2016, 138, 10100-10103. [CrossRef]

41. Ma, D.; Li, Z.; Zhu, J.; Zhou, Y.; Chen, L.; Mai, X.; Liufu, M.; Wu, Y.; Li, Y. Inverse and highly selective separation of $\mathrm{CO}_{2} / \mathrm{C}_{2} \mathrm{H}_{2}$ on a thulium-organic framework. J. Mater. Chem. A. 2020, 8, 11933-11937. [CrossRef]

42. Luo, J.; Ying, L.F.; Zhang, F.; Zhou, Z.; Zhang, Y.G. Cu(II)-Containing Metal-Organic Framework with 1D Hexagonal Channels for Cyanosilylation Reaction and Anticancer Activity on Osteosarcoma Cells. ACS Omega 2021, 6, 5856-5864. [CrossRef] 
43. Hwang, I.H.; Bae, J.M.; Kim, W.S.; Jo, Y.D.; Kim, C.; Kim, Y.; Kim, S.-J.; Huh, S. Bifunctional 3D Cu-MOFs containing glutarates and bipyridyl ligands: Selective $\mathrm{CO}_{2}$ sorption and heterogeneous catalysis. Dalton Trans. 2012, 41, 12759-12765. [CrossRef] [PubMed]

44. Kim, H.-C.; Mitra, S.; Veerana, M.; Lim, J.-S.; Jeong, H.-R.; Park, G.; Huh, S.; Kim, S.-J.; Kim, Y. Cobalt(II)-coordination polymers containing glutarates and bipyridyl ligands and their antifungal potential. Sci. Rep. 2019, 9, 14983. [CrossRef] [PubMed]

45. Hwang, I.H.; Kim, H.Y.; Lee, M.M.; Na, Y.J.; Kim, J.H.; Kim, H.C.; Kim, C.; Huh, S.; Kim, Y.; Kim, S.-J. Zn-MOFs containing flexible $\alpha, \omega$-alkane (or alkene)-dicarboxylates and 1,2-bis(4-pyridyl) ethane ligands: $\mathrm{CO}_{2}$ sorption and photoluminescence. Cryst. Growth Des. 2013, 13, 4815-4823. [CrossRef]

46. Xu, J.; Xue, D. Fabrication of copper hydroxyphosphate with complex architectures. J. Phys. Chem. B 2006, 110, 7750-7756. [CrossRef]

47. Cho, I.-S.; Kim, D.W.; Lee, S.; Kwak, C.H.; Bae, S.-T.; Noh, J.H.; Yoon, S.H.; Jung, H.S.; Kim, D.-W.; Hong, K.S. Synthesis of $\mathrm{Cu}_{2} \mathrm{PO}_{4} \mathrm{OH}$ hierarchical superstructures with photocatalytic activity in visible light. Adv. Funct. Mater. 2008, 18, $2154-2162$. [CrossRef]

48. Luo, Y.-K.; Song, F.; Wang, X.-L.; Wang, Y.-Z. Pure copper phosphate nanostructures with controlled growth: A versatile support for enzyme immobilization. CrystEngComm 2017, 19, 2996-3002. [CrossRef]

49. Jiang, L.; Kon, N.; Li, T.; Wang, S.-J.; Su, T.; Hibshoosh, H.; Baer, R.; Gu, W. Ferroptosis as a p53-mediated activity during tumour suppression. Nature 2015, 520, 57-62. [CrossRef] [PubMed] 